\title{
Laboreal
}

Volume $5 \mathrm{~N}^{\circ} 1$ | 2009

Ergonomia e desenvolvimento sustentável

\section{Conceber a actividade colectiva conjunta : o inquérito dialógico Estudo de caso sobre segurança na indústria da construção}

Diseñar la actividad colectiva conjunta : la investigación dialógica. Estudio de un caso acerca de la seguridad en la industria de la construcción

Concevoir l'activité collective conjointe : l'enquête dialogique. étude de cas sur la sécurité dans l'industrie du bâtiment

Understanding joint collective activity : the dialogic inquiry : a case study of safety in the construction industry

\section{Philippe Lorino}

Tradutor. Camilo Valverde

\section{(2) OpenEdition \\ Journals}

Edição electrónica

URL: http://journals.openedition.org/laboreal/10772

DOI: $10.4000 /$ laboreal. 10772

ISSN: 1646-5237

Editora

Universidade do Porto

\section{Refêrencia eletrónica}

Philippe Lorino, « Conceber a actividade colectiva conjunta : o inquérito dialógico Estudo de caso sobre segurança na indústria da construção », Laboreal [Online], Volume $5 N^{0} 1$ | 2009, posto online no dia 01 julho 2009, consultado o 11 outubro 2019. URL : http://journals.openedition.org/laboreal/10772 ; DOI : 10.4000/laboreal.10772

Este documento foi criado de forma automática no dia 11 outubro 2019.

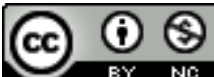

Laboreal está licenciado com uma Licença Creative Commons - Atribuição-NãoComercial 4.0 Internacional. 


\section{Conceber a actividade colectiva conjunta : o inquérito dialógico Estudo de caso sobre segurança na indústria da construção}

Diseñar la actividad colectiva conjunta : la investigación dialógica. Estudio de un caso acerca de la seguridad en la industria de la construcción

Concevoir l'activité collective conjointe : l'enquête dialogique. étude de cas sur la sécurité dans l'industrie du bâtiment

Understanding joint collective activity : the dialogic inquiry : a case study of safety in the construction industry

Philippe Lorino

Tradução : Camilo Valverde

\section{REFERÊNCIA}

Artigo original : Philippe Lorino, “ Concevoir l'activité collective conjointe : l'enquête dialogique », Activités [En ligne], 6-1 | avril 2009. DOI : 10.4000/activites.2154

\section{Introdução : performance e actividade colectiva}

1 A palavra " performance » tem uma ambiguidade semântica : tanto pode designar um resultado obtido na sequência de uma acção voluntária - performance de um desportista ou de uma empresa - como também pode designar, particularmente na sua versão inglesa, a própria consecução da acção - uma representação teatral, a colocação em cena de uma situação por um artista. Contudo a ambiguidade semântica é apenas aparente, se supusermos que a performance enquanto resultado não é mais do que um 
julgamento social pronunciado sobre uma acção deliberada, com dimensão institucional e finalizada por intenções (a corrida do atleta é ou não é julgada rápida ?). Os dois sentidos da palavra performance são portanto duas leituras duais de um mesmo fenómeno : a acção só faz sentido porque está submetida a um julgamento social sobre a maneira como responde às expectativas, o julgamento só tem alcance social e prático porque se aplica a uma acção concreta organizada. A performance é assim a conexão da acção com um julgamento feito sobre a acção. Aqui interessar-nos-emos por uma forma particular da performance, que se reveste de um profundo significado tanto do ponto de vista social como ético : a segurança do trabalho. A palavra “performance " está geralmente mais associada a uma leitura económica da actividade : ela é produtiva ou não, o seu custo é elevado ou baixo, responde ou não às expectativas do cliente ? No entanto, esta associação quase automática entre " performance » e " económico » não é de todo evidente. $O$ conceito de performance reenvia apenas para o facto de que toda a actividade social organizada

responde a finalidades, e que, enquanto tal, procede dos julgamentos sobre a maneira como satisfaz essas finalidades. A segurança, a produtividade, a penosidade, a qualidade, a estética, a manutenção corporal na prática de um desporto, constituem registos potenciais do julgamento de performance.

Não há performance fora da actividade, como também não há actividade sem performance : a dimensão avaliativa é constitutiva da actividade e da sua capacidade para produzir sentido ; reciprocamente, a performance - aqui, a segurança do trabalho - só se pode construir a partir duma compreensão dos dinamismos da actividade e do que, nela, ocasiona situações de risco. Entre actividade e performance há uma ligação incontornável.

4 Precisemos de imediato que, por " actividade " entenderemos " actividade colectiva ". Actividade "forçosamente" colectiva: toda a experiência vivida da actividade é experiência de uma actividade implicando uma pluralidade de sujeitos e socialmente organizada, isto porque a actividade humana é, a diversos graus, aprendida (com os outros), instrumentada e regulada (pelos outros), reflectida nos códigos da linguagem (partilhada com os outros), dirigida a um público ou a um receptor, etc. $\mathrm{O}$ sujeito cartesiano mergulhado na sua meditação metafísica sobre o mundo não é activo e não pode sê-lo, porque se pretende " fora do mundo » mesmo se o filósofo Descartes, está com toda a evidência mergulhado no mundo, quando ele escreve as "Meditações metafísicas » para as publicar através de um editor e conseguir que os leitores as leiam, apesar dos obstáculos e dos perigos políticos envolvidos. Para além de um julgamento superficial sobre o isolamento material ou a competência técnica única do actor, toda a noção de actividade individual só pode ser uma construção abstracta elaborada a partir de experiências situadas em contextos sociais e colectivos. Contudo, também é necessário precisar que, por "colectivo", não entendemos aqui uma abordagem " holista " do colectivo, que oporia " colectivo" a "individual», numa abordagem dualista. Veremos mais adiante que os termos “interaccional» ou "dialógico" qualificam esta abordagem da actividade de maneira mais precisa do que "colectivo". Trata-se de recusar a noção de " actividade individual » e a sua conotação subjectivista, e além disso, o impasse do dualismo "individual/colectivo", mas não de afirmar a existência de um qualquer sujeito " colectivo " que se imporia aos indivíduos. 


\section{Um quadro teórico centrado na actividade colectiva conjunta}

\subsection{A actividade conjunta como figura privilegiada da actividade colectiva}

5 A divisão do trabalho impõe, para que a actividade possa produzir resultados ou, noutros termos, ser "performativa", que se conjugue num conjunto de actos coordenados, cooperativos e concertados, contributos individuais múltiplos, que mobilizam uma diversidade frequentemente considerável de competências, de profissões e de funções. As organizações constituem-se nomeadamente por razões de ordem prática, para originar processos sociais complexos que exigem a intervenção conjunta de múltiplos actores. Quaisquer que sejam as formas jurídicas e as fronteiras formais das instituições envolvidas, " a intervenção conjunta de actores múltiplos " constitui de facto uma organização. $O$ desenvolvimento das profissões e das técnicas da empresa e a especialização dos meios (máquinas, sistemas de informação) reforçam os imperativos de conjugação (conjugar competências e recursos complementares) e de cooperação, consequentemente de organização (Chandler, 1977). O crescimento dos mercados e o progresso técnico traduzem-se numa complexificação técnica, social e espacial dos processos que, ao complexificarem-se, fazem exigências “de" organização, consequentemente “ das » organizações. Uma figura privilegiada da actividade colectiva é aquela que envolve práticas individuais diferentes e complementares, mais do que aquela que envolve práticas individuais similares : mais a actividade conjunta do que a actividade comum (Vernant, 1997).

Para aperfeiçoar esta análise, recorramos aos conceitos de " solidariedade mecânica » e de “solidariedade orgânica» da sociologia durckeimiana (Durkheim, 1893-2007, pp. 110-111). A solidariedade mecânica é a que anima os membros de um grupo de um espírito de cooperação orientado por valores e uma inspiração partilhada, por exemplo no seio de uma mesma profissão, enquanto que a solidariedade orgânica é a que se impõe de facto, pela necessidade prática, aos participantes numa mesma aventura cujo resultado estampará em parte os seus destinos individuais : “ a ideia de um grupo cujos indivíduos seriam orientados na mesma direcção está nos antípodas da ideia de Durkheim da solidariedade orgânica, que tem na sua base a noção de interdependência regulada, em contraste com uma noção de orientação comum das sensibilidades [...]. A tripulação do barco, no aspecto da interdependência dos destinos e da necessidade de sobrevivência, impondo as cooperações apesar de e com as diferenças de sensibilidades e de carácteres, poderia ser o paradigma da solidariedade orgânica [...]. Esta solidariedade (orgânica) resulta precisamente da necessidade de realizar uma acção com êxito. Ela não supõe de maneira alguma, pelo contrário, uma ligação de tipo “ clã » que poderíamos observar, nos meios da aeronáutica, no interior de cada uma das categorias de actores, por exemplo os pilotos, os controladores...» (Girin, 1995). A solidariedade mecânica encontra-se por exemplo na animação social interorganizacional das profissões: "o facto dos indivíduos pertencerem à mesma organização não provoca necessariamente que se estabeleçam entre eles ligações de tipo clã [...]. As solidariedades de tipo clã são frequentemente exteriores à organização, atravessam-na: entre comerciantes, entre financeiros, entre engenheiros... » (Girin, 1995). Inversamente, a solidariedade orgânica da actividade conjunta põe em jogo as 
características profundas das organizações em que ela se joga : quais são as tecnologias mobilizadas (que redes de comunicação entre os actores da actividade conjunta, que dispositivos de deslocação físicos, por exemplo a cadeia de montagem), quais são as definições dos postos e missões que regulam a divisão local do trabalho, quais são os modos de coordenação privilegiados pela organização, quais são os sistemas de incentivos que veiculam as normas de comportamento organizacionais, aí incluído os modos de cooperação, que arranjos do tempo e do espaço a organização impõe aos actores " conjuntos»?

\subsection{0 “ processo ", manifestação fenomenal da actividade conjunta e ângulo morto da investigação}

7 A partir dos anos 80, as abordagens da Qualidade Total (Imai, 1990) produzem modelos formalizados da empresa fundados sobre arquitecturas de processos (modelo europeu EFQM [1], por exemplo), enquanto que, em controlo de gestão e em contabilidade, a abordagem $\mathrm{ABC}\left[{ }^{2}\right]$ propõe medir e controlar os custos e os desempenhos das empresas a partir da decomposição em actividades e processos (Kaplan, 1984 ; Kaplan \& Johnson, 1987 ; Lorino, 1991). Com a abordagem ABC, o projecto de converter a modelização funcional clássica da empresa, por profissões, numa modelização dinâmica por fluxos e processos poderia constituir, historicamente, um momento de alteração da ideologia gestionária, de uma filosofia eminentemente funcional (por profissões) para uma filosofia eminentemente "processual», por cadeias de actividade finalizadas por um resultado prático a produzir. Um pouco mais tarde aparecem as abordagens denominadas de "Business Process Re-engineering (" reengenharia dos processos ») (Hammer, 1990), que procuram reagenciar a organização da empresa em torno dos seus principais processos, apoiando-se frequentemente nos sistemas de informação " processo orientados" (por exemplo o "workflow»). As ideias do "Business Process Re-engineering " reencontram-se na emergência seguida de difusão espectacular dos sistemas de gestão ditos integrados ERP[3]), tais como o SAP [4]. Estes sistemas, que passaram a ser verdadeiros standards no domínio da gestão das empresas, estão geralmente alicerçados numa "arquitectura de processos", isto é sobre uma modelização dos fluxos de informação assente sobre conjuntos inter-funcionais de tarefas finalizadas (processos de aprovisionamento, processos de produção, processos de venda...).

8 Há mais de vinte e cinco anos falamos, assim, muito de “ processos » nos domínios mais variados da gestão (Lorino, 1995). 0 sucesso desse termo, durante um período tão longo e em campos de aplicação tão diversos, não pode ficar a dever-se a uma simples moda. Naturalmente, o termo “ processo » designa realidades muito variáveis de acordo com os domínios de aplicação e as empresas. Mas em gestão designa sempre a cooperação de actividades que não se caracterizam pela sua semelhança, mas pela sua complementaridade para alcançar um certo tipo de resultado, portador de sentido no plano técnico, económico ou social. Propomos portanto ver na noção de processo a manifestação fenomenal da actividade colectiva conjunta na organização. Os processos aparecem como conjuntos coordenados de actividades locais permitindo, pela sua conjunção, produzir um elemento de valor para um cliente (novo conceito de produto, produto pronto para entrega, encomenda satisfeita, factura, orçamento, intervenção do serviço pós-venda...) ou um elemento de funcionamento interno importante (orçamento, pagamento do pessoal, encerramento das contas, intervenções de 
manutenção...). Para desenvolver um novo conceito de produto, entregar uma encomenda ou emitir uma factura, é preciso combinar um número frequentemente importante de actividades situadas em entidades organizacionais múltiplas e fazendo intervir diversos perfis funcionais. As actividades do processo estão ligadas por relações de coordenação fortes, e consequentemente atravessadas por fluxos de informação intensos. Contrariamente a uma representação frequente nas ciências do engenheiro ou em ciências da gestão, os processos raramente funcionam de forma sequencial, as relações complexas de interdependência entre actividades não podendo reduzir-se a relações input-output.

9 Com efeito, com o aparecimento do taylorismo (Taylor, 19111972), surgiu o projecto de reduzir o processo à sua base técnica : as instrumentações, aí incluídos os sistemas de informação, e a descrição normalizada dos modos operatórios. Esta base técnica está envolvida na actividade concreta, no dia a dia, das equipas em presença, que the interpretam o significado prático para conceber a sua acção em situação. 0 taylorismo tenta eliminar a parte interpretativa do processo e a improvisação situada. A actividade colectiva conjunta assim objectivada pode tornar-se objecto de concepção e de prescrição por parte dos especialistas e dos organizadores, fora do campo das operações (Lorino, 1987, 1989). Os desenganos do taylorismo, particularmente nos anos sessenta com a " crise do trabalho " (Coriat, 1994), conduzem diferentes teóricos e praticantes da gestão a recolocar em primeiro plano a dimensão humana do processo de trabalho, no quadro do que chamaremos, de forma genérica, " escola das relações humanas ", a abordagem ergonómica ou a análise sócio-técnica. No essencial, este movimento foca a sua crítica do taylorismo na necessidade de encontrar a dimensão subjectiva da actividade e a profundidade fisiológica e psicológica dos actores. Passamos do objectivismo tecnicista taylorista para o subjectivismo das relações humanas, sem verdadeiramente nos interessarmos pela natureza interaccional da actividade. A corrente das comunidades de prática (Lave \& Wenger, 1991 ; Wenger \& Snyder, 2000) emerge a partir de uma abordagem sociológica centrada, como o seu nome indica, sobre as práticas comuns, consequentemente sobre uma figura da actividade colectiva que advém mais da animação profissional do que da vida interna da organização. As questões de identidade, de colocação em rede, de partilha, em termos durkheimianos : de solidariedade mecânica, marcam o desenvolvimento da investigação sobre as comunidades de prática, mais do que as questões de cooperação e de construção interprofissões do sentido no trabalho.

Decididamente, certas correntes da investigação em gestão interessam-se pela complexidade interaccional, nomeadamente as investigações sobre a gestão por projectos (Clark \& Fujimoto, 1991; Midler, 1993) ou sobre a gestão das actividades de concepção (Hatchuel, Le Masson \& Weill, 2002). Mas ficaram a meio do caminho e não rompem com a visão da organização de tipo informacional e de tomada de decisão. A investigação sobre a gestão por projectos permanece fortemente ancorada no paradigma do tratamento da informação. Tenta ultrapassar a visão funcional e racionalista da organização através do recurso ao conceito de projecto como colocação entre parêntesis da organização, numa aventura de excepção e numa temporalidade marcada pela descontinuidade (início/fim do projecto), afastada das actividades recorrentes ordinárias. Os limites deste tipo de abordagem para compreender as dinâmicas organizacionais levaram recentemente alguns dos seus autores a distanciaremse dela para restabelecer uma visão mais integrada e uma temporalidade mais contínua da organização, aliás assinalada pelo uso do termo "processo »: "a 
firma não pode mais contentar-se em gerir eficazmente alguns projectos. Para comercializar um fluxo regular de produtos sempre mais inovadores, é o conjunto do processo (sublinhado por nós) de concepção, da definição da estratégia à organização da investigação, que deve ser repensada. Vemos então desenvolver-se um processo de aprendizagem organizacional que se desenrola no interior das empresas e entre os sectores, os diferentes modelos difundindo-se bastante rapidamente » (Midler \& Lenfe, 2003). Os domínios da concepção e da inovação permanecem contudo identificados como zonas específicas da actividade colectiva e da organização.

11 Quanto à corrente das “ organizações orientadas para a concepção " (Hathuel et al., 2000), ela também não rompe com a dicotomia “ actividades de concepção » versus " actividades de execução ", ligado ao paradigma de decisão. O recurso ao tema “prescrição" fortemente conotado, é significativo a este respeito: "relações de prescrição permanecem necessária à acção » (Hatchuel et al., 2002). Lembremos a este propósito a definição dada pelo Grand Robert : " ordem expressamente formulada, com todas as precisões úteis ». Os autores moderam o termo qualificando-o primeiro de prescrições "fracas", "objectos de trabalho que são também objectos de conhecimento » e " permitem uma primeira orientação e uma repartição provisória das tarefas ». Com o enfraquecimento do conteúdo prescritivo da prescrição, não parecemos mais próximos do que poderíamos chamar de signos ou artefactos mediadores, deixando uma parte significativa à improvisação colectiva situada, interpretáveis e fazendo sentido para os actores em situação. Mas porquê então falar de prescrição em vez de mediação ou de signo ? Compreendemos esta escolha abordando a segunda noção de prescrição à qual estes autores recorreram, a "prescrição recíproca", que "se aplica desde que a aprendizagem de um é modificada pela aprendizagem do outro ». Esta definição só tem sentido se existirem situações em que, ao contrário, a aprendizagem de um não é modificada pela aprendizagem do outro. A interacção aparece portanto como um transplante contingente sobre uma situação de base em que os actores aprendem subjectivamente e separadamente uns dos outros, a aprendizagem de um interagindo às vezes com a do outro, nos antípodas de uma abordagem interaccionista da organização, para a qual a organização é por essência interacção - quanto mais não fosse papel mediador permanente da linguagem, fundador do pensamento e da acção. Esta visão de um interacionismo por excepção é confirmada pela referência dos autores à noção de "racionalidade interactiva " desenvolvida por Jean-Pierre Ponssard e Hervé Tanguy (Ponssard, \& Tanguy, 1993) : “face à incerteza ou a meios instáveis, a forma de racionalidade privilegiada não é de natureza mecânica : um actor isolado, com modelizações tão robustas quanto possível e para o qual o motor da decisão é a incitação individual. É preciso substituir-lhe a noção de racionalidade interactiva. Esta racionalidade não é universal, mas emerge na interacção entre vários actores que utilizam uma modelização comum do real como referência para a acção ; neste quadro, o motor da decisão colectiva é a procura de um ponto focal para o qual tendem todos os actores envolvidos ». Por um lado, a visão interaccional intervém por derrogação de um actor isolado, que efectua modelizações e tomando decisões a partir de incitações individuais, próximas do decisor cognitivista ou do homo economicus. Por outro lado, desde que, confrontado com a incerteza, este decisor racional coopera com outros, é necessariamente na base de representações partilhadas do real (modelização comum do real, aí incluído o "ponto focal partilhado »). As práticas gestionárias e a sua teorização empírica estão portanto, desde 
os anos 80, marcadas pela questão recorrente da dimensão interaccional de toda a acção, particularmente por razões de performance.

Enquanto actividade colectiva conjunta, o processo apresenta duas dimensões complementares essenciais. Por um lado, é interaccional : para que se possa realizar, é necessário que os diferentes actores implicados interajam entre si de todas as maneiras possíveis : equilibração dos volumes de actividade, revisão das normas, sincronização, atribuição coerente dos recursos, circulação de informações e de objectos... Estas interacções são marcadas pelo cunho da heterogeneidade. Por exemplo, para que seja realizada uma compra de peças de substituição, é necessário que um agente de manutenção defina a necessidade de uma compra (competência técnica), que um gestor de stocks verifique a existência da peça em stock (competência logística), que um controlador de gestão verifique a disponibilidade orçamental para essa compra (competência gestionária) que um comprador escolha fornecedores potenciais, negoceie com eles e efectue a encomenda (competência de compra), que um contabilista processe a transacção de compra nas contas da empresa (competência contabilística), que um técnico - não necessariamente o mesmo do início - recepcione a peça e verifique a sua conformidade com a encomenda (competência técnica)...

13 Além disso, fala-se de processo pelo facto de permitir, pelas cooperações que desencadeia, a realização de uma transacção com o mundo, uma "transacção intramundana " (Vernant, 1997) : a produção de um serviço ou de um produto, o fornecimento de um orçamento a um cliente potencial, a resposta a um pedido de informação, a realização de uma compra... As interacçães no seio do processo devem portanto ser reguladas de forma a que a transacção global se realize em condições satisfatórias, e reciprocamente, a transacção deve ser concebida e gerida de modo que as interacções sejam realizáveis em condições socialmente aceitáveis (de custo, de segurança, de prazos...). A coerência entre transacção e interacções pode apoiar-se, de maneira mais ou menos estável e recorrente, sobre regras e normas retiradas da experiência colectiva, mas nunca é assegurada de forma automática. Em graus diversos, ela deve ser sempre reconstruída dinamicamente em situação. Esta reconstrução situada da coerência transaç̧ão/interacções é particularmente aberta, por exemplo, nos sectores com forte evolução tecnológica ou nos sectores de serviços personalizados, nos quais o resultado transaccional do processo é parcialmente redefinido em cada ocorrência.

\subsection{O processo é definido pelo inquérito reflexivo dos actores}

14 Há imensas maneiras de definir os processos numa empresa. Descrever a organização em termos de processos, é designar as lógicas transaccionais e interaccionais que julgamos dominantes (quais são as coordenações mais importantes? Quais são os “ outputs » transaccionais mais significativos ?), exprimir, portanto, a visão que temos da actividade colectiva. Às vezes, os próprios actores do processo entregam-se a si mesmos a uma reflexão colectiva sobre a sua própria actividade colectiva, para avaliar e, se for caso disso, transformá-la. Não é forçoso que esta reflexividade colectiva seja claramente formalizada : pode resultar de trocas quotidianas relativamente rotineiras. Por exemplo, num processo de compras, o contabilista, na ocasião de um contacto banal com um técnico de manutenção, assinalalhe: "sabes, a propósito, quando fazes um pedido de compra, para definires a tua necessidade, indica no formulário se é para manutenção corrente ou se é uma grande operação programada, isso pode ajudar-me ». 
Não se trata de uma troca discursiva estritamente operacional, directamente envolvida no desenrolar do próprio processo e destinada a regular uma acção precisa. Estamos de certa forma em "modo comentário", como o indica a formulação genérica num presente recursivo : " quando fazes um pedido de compra... ». Estas trocas quotidianas traduzem-se, ao longo do tempo, por uma reconcepção progressiva, por pequenos retoques do processo : o técnico preencherá diferentemente o pedido de compra.

Ao analisarem reflexivamente o seu processo, os actores constroem-no de facto como objecto de pensamento. É ao analisá-lo, ao avaliá-lo, ao discuti-lo e ao modificá-lo que os actores podem enagi-lo, isto é fundá-lo como experiência de vida. "A expressão precede a experiência, afirma Bakhtine. Ela é o seu berço » (Bakhtine Voloshinov, 1925). É exprimindo o seu processo que os actores fundam a experiência : "O colectivo passa a existir porque os indivíduos crêem que ele existe, e pelo facto de ajustarem o seu comportamento ao que eles percebem como o resultado de uma acção colectiva » (Girin, 1995, sublinhado nosso). Lá onde podíamos imaginar dez maneiras de decompor processos na acção colectiva, enquanto a análise permanecia no limbo de uma reflexão teórica, a abordagem reflexiva dos actores dá um conteúdo prático a uma configuração particular de actividades, designada como processo.

16 A título de exemplo, referiremos uma experiência recente no sector da construção. Participamos [5] numa reflexão colectiva sobre a segurança do trabalho numa empresa geral de construção : como reduzir os acidentes nos estaleiros? Uma análise prévia conduziu à consideração que os parâmetros de concepção do estaleiro - a planificação, o plano de encaminhamento dos equipamentos e dos materiais, os processos construtivos adoptados, a constituição das equipas, a escolha dos fornecedores, o dimensionamento dos recursos, a preparação das operações mais delicadas - têm um papel fundamental no nível da segurança no decurso da execução do estaleiro. Assim, um grupo reuniu-se para reflectir colectivamente sobre o processo "conceber os estaleiros", com a finalidade de estudar a maneira como influi na segurança. Este grupo reunia os diversos actores envolvidos: comerciais que organizam a proposta inicial ao cliente, técnicos especializados, responsáveis pela planificação, gestores de obra, coordenadores de segurança... No decurso desses trabalhos, o grupo debateu sobre a importância de convidar um arquitecto para esses debates. Com efeito, certos membros do grupo salientaram que a complexidade e as características estruturais da obra concebida pelo arquitecto têm uma influência significativa na facilidade de construção e na perigosidade do estaleiro. Depois de uma discussão animada, o grupo decidiu não dar sequência a esta sugestão : havia finalmente um acordo maioritário que considerava que " a concepção da obra é um dado, não é assunto nosso, nós devemos adaptar-nos, a nossa função, é a de realizar em boas condições de segurança e de custo uma obra já concebida por um arquitecto ». Noutras palavras, o grupo reconhecia a existência de uma actividade colectiva conjunta "conceber o estaleiro", mas considerava que as actividades ligadas à concepção do edifício não faziam parte dela. Isto tinha consequências essenciais nas bases da aç̧ão mobilizáveis (a concepção do edifício não fazendo parte), nos sentidos do processo (" estamos aqui para conceber e executar um projecto de construção seguro e económico, qualquer que seja a concepção do edifício »), na configuração social da comunidade envolvida (os arquitectos não fazem parte dela), etc. Pudemos observar escolhas diferentes sobre o mesmo assunto, com outros actores tendo uma experiência diferente (por exemplo um gestor de obra tinha trabalhado no estrangeiro, num contexto em que as separações dono de obra/ 
empreiteiro geral/empresa geral não são tão rígidas como em França, e ele incitou o grupo em que participava a incluir a concepção do edifício no processo "conceber o estaleiro »).

17 A retrospectiva reflexiva dos actores sobre o seu processo é desencadeada por uma situação de surpresa - por exemplo, um problema de qualidade, de segurança, de custos - ou uma dúvida: a convicção difusa de que "poderíamos fazer melhor ", e que o processo não responde de maneira satisfatória às expectativas a seu respeito. Doutra forma porque preocupar-se com ele ? O sentido global do processo é posto em causa, fende-se. Os actores estão assim sempre confrontados, sob modalidades diversas, com a mesma questão : como reconstruir o sentido do processo, para poder continuar a agir juntos? Diríamos, recorrendo a um conceito desenvolvido por Peirce (Peirce, 1958), que a retrospectiva reflexiva sobre a actividade desencadeia-se a partir de um raciocínio abdutivo: face a uma situação não conforme às expectativas, os actores devem construir uma hipótese, um novo quadro narrativo no âmbito do qual a situação encontrada volta a ser inteligível e accionável. 0 raciocínio abdutivo apela a uma certa criatividade e a registos interpretativos inabituais dado que os registos habituais postos em falência. Produz-se em qualquer domínio da actividade, e não especificamente nos domínios reservados à concepção ou à inovação. Desenvolve-se num quadro interaccional de proposições, de controvérsias e de admirações.

Se ocorrer, esta troca reflexiva não é suspensiva. Ela não interrompe o desenrolar habitual do processo : por um lado, as obrigações operacionais não são geralmente interrompidas pela reflexão empreendida ; por outro lado, as explicações atribuídas aos problemas encontrados exigem ser testadas na prática : o processo real é de certa forma o banco de ensaio dos cenários explicativos "avançados " pelos actores. Não há um tempo para a reflexão, durante o qual a acção estaria suspensa, e um tempo para a acção, durante o qual a reflexão estaria suspensa: a reflexão desenvolve-se no desenrolar da acção, ela modifica mais ou menos continuamente as normas da acção, e obtém em retorno elementos de validação e de ajustamento, e isto, num fluxo contínuo de experiência e de pensamento. Esta imbricação da acção e da reflexão não exclui que por uma questão de método possa ser necessário organizar por vezes um tempo de afastamento em relação aos fluxos das actividades correntes para repensar a actividade. Mas este afastamento é apenas um desvio heurístico, uma etapa na organização espácio-temporal da acção vista na sua complexidade, e não como pura execução. Estes tempos de recuo são comparáveis ao gesto do pintor que dá um passo atrás para contemplar num instante com um olhar diferente e mais distante o quadro em processo de criação. Postular que é preciso sair da acção para a repensar, seria voltar ao dualismo cartesiano pensamento/aç̧ão. A abordagem imbricada de reflexão e da experimentação das práticas novas corresponde ao que os pragmatistas, em particular Peirce e Dewey, chamam o “inquérito » (Dewey, 1938). A acção inteligente e o pensamento reflexivo são inquérito, construção abdutiva de hipóteses desenvolvidas pelo raciocínio e experimentadas, mistura indissociável do pensamento e da acção.

\subsection{0 “ processo " é uma construção dialógica do sentido}

19 Na retrospectiva da actividade colectiva, os actores necessitam uns dos outros. O nível de reflexividade e a amplitude das transformações possíveis dependem amplamente do desenvolvimento do diálogo. Se a reflexividade fica acantonada num quadro individual e estritamente local, o leque de transformações possíveis é reduzido. Apenas em 
aparência um processo é constituído por actividades individuais coordenadas. Na realidade, o processo não resulta da coordenação de actividades individuais, assim como uma conversação não resulta da coordenação de monólogos. Tal como acontece com os enunciados de uma conversação, as actividades locais de cada um dos actores implicados no processo não são "individuais ». A sua pertença ao processo e a sua natureza social estão inscritas na sua própria natureza, nas suas características, na sua instrumentação e no seu desenvolvimento, quer os actores disso tenham ou não tenham consciência. A actividade de cada actor é literalmente "dirigida " aos outros actores do processo, em todas as suas dimensões : discurso, gestos, posturas corporais, mímicas. Se retomarmos o exemplo do processo " compras ", o técnico de manutenção deve definir a sua necessidade de forma a ser compreendido pelo seu colega comprador. Ele procura responder por antecipação às questões que o comprador lhe poderia colocar para consultar os potenciais fornecedores. Se o mesmo técnico tentar explicar a sua necessidade de compra a um colega técnico do mesmo serviço, não utiliza os mesmos termos e não fornece as mesmas informações. A actividade "definir a necessidade de compra » não seria de todo a mesma, dado que no seu próprio conteúdo, esta actividade leva em conta o seu destinatário. Consequentemente, se o actor directo da actividade do técnico é obviamente o próprio técnico, o comprador destinatário desta actividade e especificador tácito do seu conteúdo é seu co-autor. A conduta concreta da sua actividade por cada um dos actores do processo responde às actividades de outros actores, antecipa as respostas (ou não respostas) que estes lhe darão, sincroniza-se com outras actividades desde que estas ocorram, e por vezes integra como elemento significativo a nãoactividade dos colegas. É tomado em conta o que certos actores não fazem, e que noutras circunstâncias teriam feito, e o que eles não fazem porque "é evidente ». Observemos assim que, no caso apresentado anteriormente, o risco assumido pelo operador no estaleiro, o trabalho em condições acrobáticas proibidas pelos regulamentos, o corpo torcido para alcançar um objecto de acesso difícil, relacionam-se com lacunas das actividades de concepção e de preparação.

O processo apresenta-se assim como uma troca dialógica (Bakhtine, 1970 ; Todorov, 1981), uma " conversação em actos », na qual as actividades concretas desempenham a função de enunciados discursivos situados e o reportório de acções genéricas mobilizado no processo fornece uma linguagem partilhada pelos actores do processo. Estas acções genéricas não se reduzem a “ tarefas " (por exemplo o uso " normal » de um instrumento), mas englobam modos de coordenação e de comunicação que tornam possível a improvisação colectiva em situação. A actividade de cada um "fala " aos outros, através da referência a géneros profissionais, a tarefas genéricas, ao desenrolar de processos tipo, a encadeamentos ou modos de cooperação recorrentes, e a significados veiculados pelos instrumentos. 0 dialogismo da actividade colectiva põe em relação, não apenas sujeitos psicológicos, mas também papéis-tipo e funções, no quadro de uma divisão do trabalho culturalmente consagrada. No exemplo do processo de compra citado anteriormente, se o técnico de manutenção de uma central hidráulica da EDF precisa de comprar uma peça cujo código de artigo só está autorizado para centrais nucleares, encontra-se em situação de improvisação. Pode escolher entre várias possibilidades : pedir que alarguem o uso deste código às centrais hidráulicas, pretender assim uma modificação estrutural do sistema de informação; tentar encontrar um código alternativo, único, com o risco de se perder na imensidão dos códigos de artigo ; dirigir-se ao comprador, com o risco de encontrar com ele uma solução que ponha problemas ao seu colega contabilista, no registo final da operação ; 
dirigir-se logo ao comprador e ao contabilista, com o risco de tornar a concertação excessivamente pesada. Qualquer que seja a orientação da sua acção, agirá sempre "no papel de " "técnico de manutenção da EDF " tendo relação com " compradores da

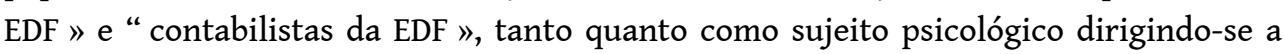
outros sujeitos psicológicos (por vezes desconhecidos). O lugar central atribuído aqui à questão da interpretação não isola portanto o sujeito no seu posto de trabalho, mas liga de forma indefectível interpretação e dialogismo. A interpretação não é solitária, mas desenrola-se na troca e pela troca. $O$ técnico de manutenção da EDF dirige a sua acção para os compradores e contabilistas da EDF em função da sua história, da sua cultura e do contexto específico em que estão inseridos.

21 A actividade colectiva estende-se portanto muito para além do quadro presencial imediato. Os processos que organizam e governam a actividade local estendem-se para fora do campo de trabalho imediatamente observável. Para se conceder os meios para compreender e transformar as situações de trabalho, é indispensável ultrapassar o âmbito local no estudo da actividade colectiva e de tomar em conta a dimensão “translocal» da actividade (Smith, 2006). A pioneira da etnografia institucional Dorothy Smith põe-nos de sobreaviso contra "the lack of hooking the local to the extralocal and trans-local" (" a falta de ancoragem do local ao extra local e ao trans-local ») (Widerberg, 2004). Como vemos, a noção de “colectivo" reenvia aqui para o desenvolvimento da troca dialógica e não tem portanto grande coisa a ver com uma visão holista da organização ou a postulação de um "sujeito colectivo " Tal como um diálogo não pode ser assimilado a um coro! Esta dimensão dialógica passa por mediações semióticas (linguagens, instrumentos) de natureza social.

\subsection{A actividade colectiva é mediatizada semioticamente}

As actividades do processo são mediatizadas por sistemas de signos (Vygotski, 1997). “Não existe experiência fora da sua incarnação em signos ", constata Bakhtine (Voloshinov/Bakhtine, 1977). As mediações semióticas (descrições genéricas das actividades, tais como as tarefas normalizadas que podemos encontrar nos procedimentos industriais ou nos procedimentos administrativos, regras e normas, instrumentos, linguagens) não são representações ou simbolizações de..., mantendo uma relação unívoca com o seu objecto, mas sim mediações entre ... e ... Contrariamente à representação no sentido cognitivista, o papel prático do signo não decorre unilateralmente da maneira como reproduz mimeticamente o mundo ; ele está ligado à maneira como é interpretado pelos actores, no contexto espacial, histórico e sócioorganizacional da sua actividade $\left.{ }^{6}\right]$. Estas mediações desempenham várias funções :

- Uma função de distanciação e consequentemente de reflexividade : ao representar a sua actividade e a dos outros por signos, os actores criam uma distância entre a sua actividade e eles próprios, e possibilitam assim os meios para fazer a retrospectiva sobre a sua própria actividade, de falar sobre ela, de a reflectir ; a actividade passa a ser objecto de reflexão e de debate.

- Uma função de abstracção : a actividade concreta e situada aqui e agora é única : é possível construir uma aprendizagem e capitalizar a experiência sobre actividades singulares; a mediação semiótica permite relacionar a actividade única hic et nunc a classes genéricas da actividade, a " géneros » da actividade (Dewey, 1938 ; Clot, 1999 ; Clot, \& Faïta, 2000) [7], e de se abstrair assim da singularidade da experiência situada. 
- Uma função de socialização : nos signos encontramos os outros, aqueles que os conceberam (por exemplo, os conceptores dos instrumentos) aqueles que os utilizam concorrentemente (por exemplo, os utilizadores de um mesmo equipamento, ou de uma mesma aplicação informática, ou de um mesmo vocabulário), aqueles que interpretam os signos que emitimos (na forma e no conteúdo dos signos que emitimos já temos em conta o interlocutor e a sua actividade), além disso, os sistemas de signos envolvidos na actividade, ao constrangerem a realização colectiva do processo, impõe-lhe uma certa coerência através do tempo e do espaço sócio-organizacionais.

- Uma função de memorização : o signo permite preservar o traço de uma actividade passada ; pode facilitar a sua reprodução, que nunca será idêntica mas que economizará as aprendizagens através do reenvio para a experiência.

- Uma função de configuração espácio-temporal : o signo permite presentificar na situação elementos do contexto e actividades localizados em espaços longínquos (por exemplo, noutros países e noutros sítios) ou em tempos distantes no passado ou no futuro : o signo oferece portanto uma certa possibilidade de configurar o espaço e a temporalidade da actividade colectiva ao libertar-se dos constrangimentos físicos imediatos.

\subsection{Ultrapassar os dualismos : constrangimento e habilitação, objectivismo e subjectivismo}

23 Em todas estas funções, a mediação semiótica produz simultaneamente efeitos de constrangimento e de habilitação. Constrangimento e habilitação estão directamente ligados :

- A mediação segmenta contínuos. Por exemplo. O vocabulário das cores segmenta nomes de cores, o contínuo físico das frequências luminosas estendendo-se entre 4,3 e 7,5 x 1014 hertz em 7 ou 8 . 0 sistema de gestão industrial segmenta o trabalho de produção em operações.

- A mediação esmaga a complexidade multidimensional da experiência em leituras reduzidas a um número limitado de dimensões. Designar as actividades pelo seu custo, a sua capacidade ou a sua taxa de acidentes é obviamente um grande empobrecimento.

- A mediação delimita e constrange as possibilidades interpretativas. De uma língua para a outra, o vocabulário da linguagem natural renuncia a numerosas possibilidades de expressão, porque toda a língua natural se constrói sobre tais renúncias. Por exemplo o espanhol tem dois verbos "ser" distintos, designando o ser existencial e o ser circunstancial, nuance que o francês não tem, mas o francês distingue a acção " d'attendre " da acção " d'espérer », que o espanhol não pode fazer...

24 A mediação semiótica empobrece portanto restringindo, por princípio. Mas são precisamente os constrangimentos que ela impõe que tornam possíveis a reflexividade, o pensamento, a socialização ou a memorização. Por exemplo, o carácter constrangedor da mediação do trabalho pelas normas e regras cria a previsibilidade mútua entre actores e funda o espaço da cooperação: estando o meu colega constrangido na sua acção, posso antecipar parcialmente a sua acção futura. A mediação possibilita assim formas de actividade colectiva e de desenvolvimento da actividade que não seriam possíveis sem ela. Em qualquer caso, toda a actividade consciente é mediatizada, quanto mais não fosse pelo discurso interior. Não se deve portanto pensar constrangimento e habilitação como duas funções antagónicas da mediação (constrangimento contra autonomia, empobrecimento contra enriquecimento, etc.), numa visão dualista e cartesiana, mas como dois aspectos indissociáveis de toda a mediação por signos. Não 
há discurso - e não há pensamento - sem vocabulário e sintaxe, porque o vocabulário e a sintaxe constrangem o campo dos possíveis.

o julgamento sobre o valor de uma mediação deve portanto interessar-se mais pelos seus efeitos práticos do que por uma hipotética dosagem entre nível de constrangimento e nível de autonomia. Tais abordagens dualistas conduzem a debates tão estéreis como “ que quantidade de regras é necessário ? (do género “ as regras são indispensáveis à segurança » versus “ as regras matam a iniciativa e consequentemente a segurança ») ou " que quantidade de indicadores são necessários ", debates nos quais substituímos as arbitragens quantitativas e simplificadoras da enumeração pela questão evidentemente mais complexa do julgamento e do sentido (" que jogo de regras faz sentido para os actores?»).

Bakhtine (Bakhtine, 1978, citado por Todorov, 1981) critica duas derivas empiristas na análise dos enunciados :

- Um empirismo " objectivista ", que se interessa exclusivamente pela matéria linguística dos enunciados, como se o seu sentido fosse inteiramente conteúdo na codificação semiótica ; encontramos correntemente o mesmo tipo de derivas para as actividades colectivas nas organizações : é a abordagem que reduz os processos à sua dimensão técnica, postulando que os dispositivos técnicos - por exemplo, as prescrições formais, os processos tecnológicos dão conta integral do processo e determinam-lhe o decurso.

- Um empirismo " subjectivista ", que se interessa exclusivamente pelo psiquismo do autor do enunciado, como se ele estivesse isolado na sua actividade discursiva, ignorando a dimensão dialógica e mediatizada de todo o enunciado, aí também, encontramos a mesma deriva na análise e gestão prática dos processos, quando tentamos compreender o processo apenas pela análise das dinâmicas psicológicas dos actores; Yves Clot, justamente, salienta que o actor nunca está sozinho na sua actividade, ele dialoga com “o género », o que outros antes dele fizeram e que outros depois dele farão, ou o que os colegas fazem em tarefas similares às suas; podemos acrescentar que o actor também “ dialoga em actos » com os seus colegas de processo, que mobilizam no mesmo processo " géneros" de actividade diferentes do seu. $\mathrm{O}$ actor nunca está sozinho face ao objecto do seu trabalho e face aos meios técnicos de que dispõe : o trabalho aparentemente mais solitário é de facto “ povoado " por uma multidão de “ interactores » com os quais o sujeito dialoga através do espaço, do tempo e da organização.

\subsection{A constituição de um “ cronótopo » da actividade colectiva}

Para a sua retrospectiva reflexiva sobre a actividade colectiva, os actores desenham a sua configuração espacial, temporal e sócio-organizacional. Ao conceber em conjunto o processo como seu, eles desenham-lhe um perímetro virtual, limites e balizas cronológicas, espaciais e sociais, o que, em critica literária Bakhtine chama um “ cronótopo »: " o cronótopo determina a unidade artística de uma obra literária na sua relação com a realidade » (Bakhtine, 1978). Nós alargaremos aqui a formulação de Bakhtine observando, a propósito dos processos, que o cronótopo determina a unidade prática de uma actividade colectiva na sua relação com o mundo. É num cronótopo particular que os actores dão sentido ao processo. Disso vimos um exemplo com o processo “ conceber e preparar os estaleiros " no domínio da construção : os membros do grupo estavam dispostos a inquirir colectivamente o processo, mas a história do processo começava para eles com uma obra já concebida, que fazia parte do contexto da sua actividade e não constituía objecto dela. A concepção arquitectónica era excluída do 
cronótopo desse processo. O quadro espácio-temporal finalmente retido influencia de forma decisiva o sentido das situações encontradas e os potenciais da aç̧ão que daí resultam : para diferentes cronótopos, verificam-se que o contexto, o significado e o potencial de aç̧ão são distintos. Por exemplo, qual a importância relativa dada às actividades ditas de " concepção » e de "realização " na construção de uma obra? Os próprios vocábulos de "concepção " e de "realização " remetem para abordagens tradicionais bem estabelecidas em matéria de cronótopos. A construção de uma obra joga-se em duas narrações distintas : por um lado o cronótopo da concepção, com os seus quadros temporais (início com a formulação de um projecto ou de uma intenção por um cliente, conclusão com a "reunião de transferência " em que as equipas de concepção transmitem o dossiê do projecto à equipa de construção), espacial (os gabinete das funções "projectos" e "métodos", os gabinetes comerciais) e sócioorganizacional (engenheiros de projectos, comerciais, gestores). Há por outro lado o cronótopo da realização, com os seus quadros temporal (inicia com a "reunião de transferência ", conclui com a entrega da obra ao cliente), espacial (o estaleiro), sócioorganizacional (equipas de estaleiro, chefe de estaleiro, gestor de obra). As “ atmosferas » e as culturas são contrastadas : passamos do mundo dos escritórios para o mundo do estaleiro com a reunião de transferência. As competências e as missões são claramente separadas: o engenheiro de projectos e o comercial não estão mais envolvidos no projecto após a reunião de transferência, assim como os encarregados, os operários e o chefe de estaleiro não estão envolvidos anteriormente. A distinção entre os dois cronótopos tem imensas consequências, particularmente do ponto de vista da segurança. A segurança só joga um papel secundário no cronótopo da concepção : tratase de conseguir um contrato dar o máximo para ser credível, sedutor e concorrencial. 0 “dragão dos acidentes » está relativamente ausente desta narração... Ele surge no cronótopo da realização : a segurança é uma questão da realização, consequentemente um problema do estaleiro e do controlo no estaleiro...

\subsection{Inquérito e comunidade de inquérito}

Ao sustentarem-se do seu processo, mesmo que de forma muito informal, os actores sustentam-se de facto de si próprios e da comunidade que constituem. É de resto ao constituírem-se em comunidade que podem esperar agir eficazmente para transformar e desenvolver a sua actividade colectiva : "o "eu", escreveu Bakhtine, só pode realizarse no discurso ao apoiar-se no "nós" " (Bakhtine, 1926), comentário que nos permitiremos transpor para o caso da actividade colectiva constatando que "o "eu" só se pode realizar na actividade ao apoiar-se no "nós" ». Como influir significativamente no processo de desenvolvimento de novos modelos de automóveis, ou sobre o processo de execução de um contrato de seguros, ou do processo de concessão da permissão de construção, se os múltiplos actores não se mobilizarem de forma cooperativa para inquirirem juntos o processo e o transformarem? Este inquérito é frequentemente complexo, se tivermos em conta a multiplicidade de campos e de competências envolvidas. Se um grupo de trabalho comum pode resolver problemas operatórios simples, a transformação do processo pode implicar mudanças profundas na identidade profissional e nas relações de trabalho dos actores. A situação assemelha-se à de um projecto de aprendizagem colectiva, apoiado pela constituição de uma comunidade pedagógica no seio da qual se joga a construção de uma experiência comum nova. A mudança não pode ser, nem decretada, nem “concebida e sustentada» por 
especialistas. É este tipo de comunidade que Dewey baptizou de "comunidade de inquérito " (Dewey, 1902, 1916), reunida, não em torno de uma prática comum, mas num inquérito colectivo mobilizando práticas heterogenias. As condições de existência de uma comunidade de inquérito incluem as condições políticas e gestionárias da mudança, nomeadamente o envolvimento dos centros de poder de gestão, a atribuição dos meios necessários, em particular em termos de tempo, a abertura à experimentação, a possibilidade de criticar. Pode parecer irrealista, ou até ingénuo, invocar tais condições, mas, na sua ausência, as situações de transformação arriscam-se fortemente a obedecer a decretos hierárquicos ou a fatalidades tecnológicas sofridas, com, ainda por cima, dificuldades sociais, psicológicas e económicas de todas as espécies. A multiplicação dos fracassos em matéria de grandes projectos de sistemas de informação, de reorganização (process reengineering) ou de mudança tecnológica são disso testemunho. Não nos preocupamos aqui, nem de ser realistas na descrição das práticas correntes, nem de ser normativos na definição de um alvo. Lá onde as epistemologias dualistas separam o "descritivo " e o "normativo ", aqui será antes tentado apreender a inteligibilidade do desenvolvimento organizacional.

\subsection{0 inquérito introduz no processo uma dimensão avaliativa}

Uma das características essenciais do enunciado para Bakhtine "é que ele é provido de valores » (Todorov, 1981) enquanto que a língua “é estrangeira ao mundo axiológico »: "Só o enunciado pode ser belo, como só o enunciado pode ser sincero ou enganoso, corajoso ou tímido. Todas estas determinações apenas se referem à organização dos enunciados..." (Bakhtine, 1928), e não à linguagem. A constatação vale para a actividade colectiva. Se os actores inquirem reflexivamente o processo, é porque se apercebem da existência de uma falha ou de um potencial de melhoria, de um cero ponto de vista: na base de uma vontade de transformação perfila-se necessariamente um julgamento avaliativo. É esta dimensão axiológica que sustenta a construção colectiva do sentido : quais são os valores associados ao estado actual do processo, como podemos fazê-los evoluir? Apenas a actividade concreta e situada é avaliada socialmente e pode ser dispendiosa ou competitiva, fiável ou defeituosa, segura ou perigosa. A riqueza técnica e humana do processo é radicalmente simplificada e empobrecida pela sua leitura avaliativa, mas esta dá-lhe um sentido e, por consequência, permite dar ao inquérito uma orientação prática e uma dinâmica. A actividade colectiva situada é assim submetida a ajustamentos e a modificações que desencadeia e reactiva a avaliação de performance. A avaliação dinamiza o inquérito produzindo perplexidades, insatisfações, e desvios, tanto no seu desencadeamento como no seu decurso. Se os fornecedores estão frequentemente atrasados nas suas entregas, esta constatação só desencadeará o inquérito e uma eventual acção correctiva se os actores, explicitamente ou não, acrescentam a frase "os fornecedores estão frequentemente atrasados nas suas entregas » com a palavra " demasiado", portadora da dimensão axiológica: "os fornecedores estão demasiado frequentemente em atraso ». Senão porquê inquietar-se ? Mas o papel da avaliação no inquérito não se fica por aqui. A avaliação acompanha a totalidade do inquérito, baliza-o e conclui-o. A construção, num dado momento, de um julgamento social avaliativo que liga o estado actual do processo a uma classe genérica de situações julgadas "conformes" às expectativas ou "aceitáveis" põe provisoriamente fim ao inquérito, "até nova ordem ", " esperando melhor »; porque " a verdade vive a crédito ", como salienta 
William James (James, 1907). A avaliação âncora assim o inquérito dos actores na situação singular, permitindo ao mesmo tempo de o ultrapassar pelo reatamento a valores genéricos, construídos socialmente (“eficiente, fiável, lento, seguro, perigoso... »).

\section{Um estudo de caso na construção [8]}

Apresentaremos aqui um estudo de caso longitudinal aprofundado (Lorino, 2007 ; Tricard, 2009) realizado num dos três maiores grupos mundiais do sector da construção civil e obras públicas (mais de 120000 trabalhadores em 2006). Depois de anos de esforço para melhorar a segurança do trabalho nos estaleiros, a curva de melhoria parece ter atingido um tecto. A taxa de acidentes estabiliza-se a um nível duas vezes superior ao das outras indústrias. Os responsáveis da empresa decidem explorar as razões deste bloqueio. Até então, a empresa tinha avançado dois tipos de respostas ao problema : tinha-se tentado agir sobre a psicologia e o comportamento individual dos actores (consciência da segurança, disciplina) ; tinha-se desenvolvido instrumentos e técnicas para a gestão da segurança (procedimentos, controlos, normas, tecnologias). Estes dois tipos de acção lembram as duas “ derivas empíricas » do estudo dos processos mencionados anteriormente : centrar-se sobre a subjectividade dos actores ou sobre a base técnica do processo. Certos responsáveis emitiram a hipótese segundo a qual certos factores de risco, tais como a falta de preparação, a falta de coordenação, a falta de capitalização da experiência, a pressão temporal, os sistemas de compensação inadaptados, estavam mais ligados às estruturas e práticas organizacionais do que aos comportamentos individuais. Encarregaram duas equipas de investigação, uma em organização, outra em psicologia da actividade, reportando-se ambos à teoria da actividade de Vygotsky, para explorar em conjunto a questão.

\subsection{Considerações metodológicas}

31 A investigação focalizou-se mais na actividade normal do que na análise dos acidentes, por várias razões :

- A génese de situações perigosas pode explicar-se pelas condições gerais da actividade normal.

- Os acidentes são eventos excepcionais e só fornecem uma base empírica limitada, enquanto que as situações de trabalho perigosas se produzem todos os dias nos estaleiros.

- Em parte por razões legais, a análise dos acidentes reforça frequentemente os discursos gestionários defensivos e as explicações redutoras para os comportamentos (averiguação de responsabilidades).

32 A primeira fase da investigação consistiu em observar situações concretas de trabalho, através de uma presença considerável (9 meses) em dois tipos de terreno : os escritórios onde os projectos são concebidos e planificados, e dois estaleiros de construção (recolha de imagens vídeo pela investigadora em psicologia e de notas pormenorizadas pelo investigador em gestão). 32 participantes representativos dos processos de concepção e de realização foram entrevistados, para produzir uma representação do sistema da actividade em textos e diagramas. Esta representação não tinha como objecto fornecer uma descrição exacta do processo, mas ser sobretudo um instrumento heurístico para a análise e discussão nos grupos de trabalho que se reuniram posteriormente. 
33 A percepção difundida das profissões da construção civil e obras públicas conduz à distinção clara dos processos de concepção/ planificação, por um lado, dos processos de construção no terreno, por outro lado (distinção espacial : escritório versus estaleiro, distinção temporal: fases a montante versus fases a jusante do projecto, distinção funcional : profissões da concepção, profissões da realização ; articulação em torno de um acto ritualizado e colectivo, denominado " reunião de transferência »). Um ciclo inicial de entrevistas e de situações observadas revelou que a maior parte das situações de perigo estavam estreitamente ligadas a escolhas de concepção e de planificação anteriores. Decidiu-se então focar o estudo sobre o processo " conceber e planificar o projecto de construção». Com o objectivo de simplificar, passaremos aqui para as discussões que giraram - e giram - em torno da definição e da delimitação desse processo (por exemplo, é preciso distinguir a “ concepção-planificação " propriamente dita e a " preparação do trabalho ", num horizonte mais curto ?). Numa segunda fase, foi adoptado um método de inquérito colectivo reflexivo sobre o processo, implicando os actores deste processo como co-investigadores. A investigação foi assim mais realizada com do que sobre os " participantes que agiam como co-investigadores e cosujeitos» (Raelin, 1999).

\subsection{Exigências aparentemente contraditórias}

Em muitas das situações observadas, havia arbitragem manifesta entre prazo e segurança. Na cultura da indústria da construção, a capacidade de efectuar os projectos nos prazos é o valor profissional mais importante. O gestor fiável, que tem as melhores perspectivas de carreira, é aquele que termina sempre os projectos a tempo. Todos na empresa sabem que a situação económica do grupo depende estreitamente da duração média dos projectos. Mas, além disso, os dirigentes assumiram compromissos ambiciosos sobre a segurança como prioridade estratégica. Sanções positivas e negativas são postas em prática para reforçar os mecanismos de segurança. A contradição potencial entre o prazo, encarado como uma questão de organização e de gestão, e a segurança, inicialmente vista como uma questão de comportamento individual no estaleiro, não está claramente identificada. Em última instância, menciona-se o direito de recusa dos actores : se julgam uma situação como perigosa, têm o direito de recusar a tarefa. Deriva “subjectivista " típica: a segurança é vista primordialmente como uma questão de escolha individual.

O sector da construção é fortemente concorrencial e economicamente constrangido. Consequentemente, os responsáveis da concepção e da planificação dos projectos procuram minimizar a duração e o custo dos projectos para ganhar os contratos. Eles produzem representações racionais da futura actividade (custo e tempo padrão, planos, procedimentos), " prescrições ", às quais se supões que a actividade real de construção deverá obedecer. Ulteriormente, nas fases de produção, quando a maioria das opções de concepção e de planificação estão feitas, os actores encontram inevitavelmente situações imprevistas. A gestão procura controlar os comportamentos e o respeito das disciplinas de segurança, mas também precisa que o trabalho seja feito a tempo. A gestão da segurança é isolada das operações e de alguma maneira hipostasiada, sob a forma de controladores, de regras, de incitações e de sanções, para procurar eliminar o risco através do controlo. Deriva "objectivista" típica: a actividade colectiva e a 
segurança são identificadas com imagens racionais estáticas (planos, programas, orçamentos, regulamentos, normas) e não com desenvolvimentos situados e dinâmicos.

Finalmente, os actores enfrentam imperativos de arbitragem entre segurança e prazos. Embora os suponhamos a "executar planos", eles têm muitas vezes de repensar parcialmente a actividade em situações perigosas. Eles acabam então por estabelecer compromissos para realizar atempadamente a missão "com tanta segurança quanto possível ", o que significa com frequência perigosamente. Esta contradição prazo segurança, na temporalidade do estaleiro e num quadro estrutural definido de forma permanente, é real : as equipas não podem às vezes fazer de outra forma que não seja escolher entre o risco e o atraso. Contudo, como o veremos, esta contradição, fortemente integrada na cultura do sector não é uma fatalidade e o questionar os quadros espácio-temporais dominantes poderia reduzi-la fortemente.

\subsection{0 diálogo mediatizado entre géneros profissionais}

As interacções observadas no terreno não são apenas interacções entre pessoas, mas também entre "géneros" profissionais (contabilistas, técnicos, compradores, gestores de obra, chefes de estaleiro, engenheiros de projectos...), da mesma forma que, nos textos literários os discursos não exprimem apenas a voz pessoal do autor, mas também as vozes genéricas de "géneros" sociais, estilísticas ou filosóficas (Bakhtine, 1986). Por exemplo, o gestor de obra faz pelo menos em parte o que um gestor de obra supostamente faz, ou o que pensa que um gestor de obra deveria fazer. Ele utiliza os métodos e os instrumentos habituais dos gestores de obra à sua maneira. Ele reage à actividade do engenheiro de projecto em função do que os engenheiros de projecto fazem normalmente e atribui sentido aos propósitos e aos actos situados do engenheiro de projectos referindo-se ao registo genérico dos actos e discursos " de engenheiro de projectos ». 0 diálogo que daí resulta é simultaneamente, por um lado, situado e único, por outro lado, expressão de um diálogo genérico entre o "género" “ gestor de obra » e o "género" “ engenheiro de projecto » (Clot \& Faïta, 2000).

Os instrumentos, cujo uso é simultaneamente situado e genérico, desempenham um papel essencial no desenvolvimento dessas interacções situadas e genéricas. Citemos o exemplo de uma reunião "objectivos" (fixação de objectivos financeiros) de um projecto de construção nos subúrbios parisienses. A equipa dos engenheiros de projecto que procedera ao "estudo do preço » (estudo técnico-económico prévio, que serve de base à oferta comercial) reencontrava a equipa de estaleiro, sob a alçada de dois dirigentes da empresa. A reunião visava analisar o desvio entre os dois orçamentos respectivamente elaborados por cada uma das duas equipas. $O$ orçamento calculado pela equipa encarregada do estaleiro era muito mais elevado do que o orçamento que tinha servido para vender o projecto e para planificar a margem. A análise pormenorizada do desvio era difícil porque os engenheiros de projecto e os gestores de obra utilizavam modelos de cálculo financeiro diferentes. Após três horas de discussão, o gestor de obra concluiu que não podia comprometer-se a realizar uma margem superior a 2,5\%. Os dirigentes presentes decidiram que ele deveria ser " mais ambicioso no cálculo da mão-de-obra » de forma a atingir uma margem de $5 \%$. Um mês mais tarde, o orçamento da mão-de-obra fixava uma redução de 60000 para 51500 horas. 0 sistema de orçamentação tinha mediatizado o diálogo "género a género", inicialmente organizando a opacidade mútua (dois sistemas de cálculo distintos), seguidamente 
formalizando para o futuro uma importante redução dos recursos, portanto uma redução das margens disponíveis para a reconcepção em situação.

\subsection{0 inquérito reflexivo colectivo}

Um grupo composto de nove actores representativos do processo "conceber e planificar o projecto » foi mobilizado para analisar o processo do ponto de vista da segurança do estaleiro. 0 grupo reuniu-se oito vezes três horas. Primeiro validou, com ligeiras modificações, a representação textual e gráfica do processo (representação clássica de tipo "flow-chart», exemplo típico de artefacto mediador, utilizado para sustentar a discussão dos actores sobre a sua própria actividade colectiva). Depois analisou as actividades julgadas mais críticas para a segurança. Dois problemas organizacionais maiores foram particularmente identificados pelo grupo.

Primeiro problema : os actores do estaleiro (gestores de obra, chefias de proximidade, subcontratados) não estão verdadeiramente implicados nas actividades de concepção. Esta ausência de implicação manifesta-se de diversas formas, por exemplo :

- Na resposta a um concurso, os engenheiros de projecto elaboram um ante-projecto que serve de base à proposta comercial, aí efectuando escolhas técnicas que influenciam directamente na segurança sem consultar os futuros actores do estaleiro (dos quais muitos não estão ainda designados nessa fase a montante).

- As etapas do estaleiro mais críticas para a segurança deveriam e poderiam ser identificadas desde as primeiras etapas do projecto, na fase de proposta comercial. É certamente impossível estudá-las de maneira pormenorizada e de as prescrever num etapa tão precoce do projecto, mas seria possível provisionar recursos orçamentais, de peritagem e de tempo para poder, chegado o momento, preparar as fases de trabalho delicadas. Por exemplo, as representações 3-D são unanimemente consideradas eficazes para preparar a equipa de estaleiro para enfrentar as tarefas complexas e potencialmente perigosas, mas são de utilização dispendiosa. A identificação precoce de etapas críticas permitiria utilizar tais modelos 3-D de maneira selectiva.

- Muitos dos actores que devem intervir de na concepção pormenorizada do projecto não estão ainda nomeados no início do projecto, e não podem portanto ser implicados nas primeiras fases.

41 Segundo problema : a separação, não apenas em termos gestionários, mas em termos culturais e profissionais, é profunda entre as fases do projecto, entre concepção e preparação, e sobretudo entre concepção-preparação e realização. Os actores de concepção/planificação não " se sentem » actores do estaleiro. 0 seu primeiro objectivo é o de ganhar contratos. Culturalmente, a segurança é vista como uma questão operacional, a equacionar na gestão quotidiana do estaleiro, dado que ela é essencialmente considerada como uma questão de comportamentos individuais no trabalho. Esta situação constitui o objecto de racionalizações comummente admitidas : “ a segurança não se planifica ", "fazemos face às incertezas da natureza ", " cada situação é única", "todos os estaleiros são protótipos", "é no terreno que asseguramos ». A percepção geral é assim que a segurança só pode ser ligeiramente antecipada, embora esteja exposta aos mesmos imprevistos que o prazo e o custo, que, estes, são objecto de enormes esforços de antecipação.

Os actores chave da concepção e da planificação desaparecem quase totalmente do projecto nas fases de construção. No entanto, nas primeiras actividades de preparação, 
a equipa de estaleiro recentemente posta em acção beneficiaria grandemente de um apoio técnico dos engenheiros que conceberam o projecto. Também lhes seria útil conservar um apoio técnico da sua parte ao longo de todo o projecto. $O$ conhecimento da história do projecto, das escolhas de concepção, do seu racional e da sua coerência global seria frequentemente preciosa para a preparação de curto prazo. Também não há capitalização da experiência sistemática sobre a segurança dos processos construtivos, as opções de planificação ou o desempenho dos fornecedores e subcontratados. Não há análise dos desvios entre os métodos planificados e os métodos efectivamente utilizados. A prática actual de capitalização da experiência, consistindo em exigir dos gestores de obra a redacção de relatórios a posteriori, é percebida como um formalismo embaraçoso e inútil. o grupo de trabalho julga que talvez fosse mais útil exigir que os conceptores e os planificadores consagrassem um dia por semana ou por quinzena ao acompanhamento dos "seus " projectos no terreno. Eles seriam assim actores directos das operações e poderiam assegurar uma viva capitalização da experiência. Enfim, as inevitáveis actividades de reconcepção/replanificação no terreno pela equipa de estaleiro não sendo reconhecidas oficialmente como legitimas não constituem objecto de dotação de recursos - a reconcepção/replanificação nas fases avançadas aparece sobretudo como um disfuncionamento. Atribuir-lhes recursos, seria planificar a não qualidade da concepção !

\subsection{Papel determinante do cronótopo da actividade}

43 Como vimos, o termo " cronótopo " (chronos = tempo, topos = lugar) (Bakhtine, 1986, pp. 46-50) designa a configuração social, espacial e temporal do processo. 0 cronótopo de um romance é " a forma (ou antes as formas sucessivas) que ele [o autor] teve de estruturar a experiência espácio-temporal, de forjar as coordenadas próprias para apreender a totalidade do mundo acessível (Bakhtine, 1978)». O cronótopo e assim o espaço-tempo, forjado pelo autor de uma obra literária, na qual um certo tipo de acção pode desenrolar-se e fazer sentido, um certo tipo de personagem pode tomar forma e agir de forma significante e, consequentemente, uma narrativa pode desenrolar-se de maneira inteligível para um leitor. 0 conceito de cronótopo já foi largamente retomado e alargado à compreensão dos fenómenos sociais pela antropologia, que nele viu uma forma de mostrar a unidade profunda que se instaura numa cultura entre as estruturas sócio-temporais e os sistemas de significado colectivos. Um certo tipo de evento ou de narrativa só tem sentido num dado quadro espácio-temporal, e reciprocamente, o lugar e espaço do evento ou da narrativa são únicos e estão-lhe indissociavelmente ligados. Por exemplo, o lugar e o tempo de encontro não são mais do que isto : sem o encontro, não são portadores de qualquer significado particular enquanto lugar e tempo, e reciprocamente o encontro não existe fora de um tempo e de um lugar. Os antropólogos mostram assim como os sistemas de significado e os sistemas de valor estão de alguma forma “ encarnados » num espaço espácio-temporal. Por extensão, o conceito permitenos aqui realçar a ligação profunda que une a configuração sócio-espácio-temporal do processo " conceber - planificar » (as funções " de projecto ", o mundo dos escritórios, as fases a montante do projecto "estudo de preço - planificação ») e o sistema de significados e de valores no qual esse processo se desenrola e produz sentido: a optimização técnica e económica, a ordenação temporal das tarefas, a atribuição de recursos, mas não fundamentalmente a gestão do risco, que, está ligada ao cronótopo da realização. A inclusão do arquitecto no cronótopo do processo “ conceber/planificar 
o estaleiro » modificaria a configuração espacial (o gabinete do arquitecto seria então um dos lugares do processo) e a configuração temporal do processo (a concepção do estaleiro começaria desde os primeiros esboços da concepção da obra). Quanto ao referencial de sentido, vemos que também se transformaria profundamente: sem o arquitecto, trata-se de conceber estaleiros rentáveis e seguros a partir de determinados constrangimentos arquitectónicos. Se o arquitecto entra no inquérito colectivo, o sentido do processo passa a ser " conceber estaleiros rentáveis e seguros ", aí incluindo a concepção da obra como alavanca da acção: os não arquitectos passam a ser percebidos, pela sua experiência de realização, como actores legítimos e competentes da concepção arquitectónica, eles devem estar preparados para isso, e devem responder com a sua contribuição à dita concepção arquitectónica.

A contradição entre segurança, por um lado, e os constrangimentos de orçamento e de tempo, por outro lado, evidenciada anteriormente, pode assim ser reduzida modificando o cronótopo da actividade colectiva. As características estruturais da actividade colectiva (calendário, atribuição de recursos, escolhas tecnológicas, composição da equipa, escolha dos fornecedores), definidas desde as primeiras etapas do projecto, desempenham um papel essencial na segurança do trabalho na construção. Quanto mais difícil parece ser reduzir o risco através do controlo (" to control out risk " em inglês), através das regras, das auditorias, das incitações, uma vez que a concepção está definida de forma permanente, tanto mais fácil de se reabsorver pela concepção (incluindo a planificação) (" to design out risk » em inglês), se os actores do processo (engenheiros de projecto e de métodos incluídos) conceberem colectivamente a actividade colectiva, desde as primeiras fases do projecto. Como salienta Perrow (1999), “as medidas de segurança deveriam ser concebidas desde o arranque e não acrescentadas posteriormente, porque os acrescentos são de maneira desproporcionada uma fonte de acidentes ».

Quando uma fraca antecipação em concepção se combina com uma fraca margem de manobra operacional em produção, a acoplagem estreita dos elementos do projecto (Perrow, 1984) produz situações nas quais os desempenhos económicos e a segurança se tornam inevitavelmente contraditórios. Os adágios do género "a construção é uma actividade imprevisível", "a segurança é uma questão de comportamento", " inovamos de cada vez ", " em última instância, é o homem que está face ao perigo ", desenham uma visão paradigmática da actividade que distingue dois tipos bem separados de actividade colectiva, inscritos em dois cronótopos distintos: " conceber e planificar o projecto de construção ", " realizar o projecto de construção ». O sentido dominante do primeiro processo é a optimização técnico-económica do projecto. 0 sentido dominante do segundo é a " execução " dos planos em condições satisfatórias de custo, de prazo e de segurança. É assim que os actores vêem o mundo, que os seus raciocínios são estruturados, que a divisão do trabalho é codificada, os sistemas de compensação definidos e os instrumentos concebidos. O primeiro processo fixa prescrições ao segundo, o qual tenta gerir o perigo da melhor maneira, dado que os constrangimentos dificilmente podem ser reduzidos. A actividade colectiva é enagida, no vocabulário de Weick (1979), e faz sentido para a forma como os actores a pensam reflexivamente.

Esta dicotomia entre dois universos cronotípicos não é uma abordagem deliberada dos dirigentes e dos responsáveis pelo enquadramento, destinada a assegurar a rentabilidade das operações, mas uma visão do mundo largamente partilhada e 
consolidada por desempenhos de papéis permanentes. Por exemplo, no sítio de construção de uma torre de escritórios, o chefe do estaleiro queixa-se das escolhas técnicas realizadas pelo gestor de obra e pelos engenheiros sem a sua opinião, em especial a escolha de um instrumento " high-tech " para moldar betão, inadequado à construção em condições correctas de segurança de volumes reduzidos no estacionamento subterrâneo. Quando lhe perguntamos se consultou o chefe de estaleiro, o gestor de obra responde que tentou, mas que o chefe de estaleiro não estava na altura disponível. Por seu lado, o chefe de estaleiro explica que estava então envolvido a tempo inteiro num projecto anterior e que não pode participar nas reuniões no decurso das quais as técnicas de construção foram discutidas. Até aqui, a visão dos dois actores converge de maneira coerente sobre um problema de gestão do tempo, de calendário na constituição das equipas e de definição de missões. Mas, depois de um silêncio, o chefe de estaleiro acrescenta : " se eu aí tivesse ido eles ter-me-iam pedido para me envolver nessa escolha ». Ele não pensa que esse tipo de envolvimento está nas suas missões e faz parte do género " chefe de estaleiro ». Uma outra visão do género " chefe de estaleiro » emergiu dos trabalhos de grupo, no qual participava um outro chefe de estaleiro. O grupo concluiu da necessidade para a segurança que os chefes de estaleiro fossem implicados como participantes activos na planificação do projecto e na coordenação da co-actividade no terreno. Contudo, este segundo chefe de estaleiro não achou útil que os chefes de estaleiro em geral se encontrem com o engenheiro de projecto encarregado do estudo de preço antes da proposta comercial ao cliente, apesar de que o estudo de preço define de uma vez por todas as primeiras opções de concepção. Temos aí uma outra visão, mais alargada, do género " chefe de estaleiro ", incluindo a participação nas escolhas das técnicas de construção, mas sem ascender até ao estudo do preço.

Não nos equivoquemos com o alcance conceptual e prático desta análise dos cronótopos “ concepção » e " realização ». Não se trata de recomendar, pela enésima vez, que os conceptores e os futuros construtores dialoguem e que os actores do estaleiro contribuam para a concepção/planificação. A análise proposta conduz à revisão em profundidade da própria definição de universos profissionais, de referenciais de sentido e dos conceitos. Trata-se com efeito de abolir a distinção entre o mundo da concepção e o mundo da realização tal como ela é geralmente compreendida e aplicada nas empresas e pelos investigadores, considerando que a " concepção » é :

- Não uma função, mas um processo que atravessa a totalidade do projecto,

- Não um conjunto de prescrições, nem mesmo uma troca de prescrições " recíprocas ", mas um inquérito dialógico e uma coconstrução contínua da actividade colectiva,

- Não um conjunto de escolhas repousando sobre o tratamento de informação, mas uma criação contínua de questões, do horizonte de compreensão mútua e do espaço das soluções possíveis, com um recurso contínuo à experimentação.

Trata-se de produzir um novo universo de acção e de sentido, que poderíamos designar como o processo "conceber e preparar a actividade colectiva de construção»: planificar, ordenar as tarefas, efectuar as escolhas tecnológicas, constituir a equipa, arbitrar o "fazer ou mandar fazer ", seleccionar os subcontratados e os fornecedores, adaptar a concepção ou os planos, preparar o trabalho das equipas, particularmente as tarefas críticas, rever as opções técnicas e organizacionais para fazer face a situações inesperadas...Este processo arranca desde as fases preliminares do projecto e prossegue durante toda a sua duração. Ele envolve actores tradicionalmente considerados como 
“realizadores", chamados a implicar-se activamente na concepção. Ele também envolve os actores tradicionalmente considerados especialistas da concepção e da planificação, chamados a implicar-se activamente na preparação a curto termo do trabalho e na capitalização da experiência. Esses actores exteriores ao estaleiro, conceptores, comerciais, fornecedores de tecnologia, estão de facto presentes no terreno, através dos artefactos, dos constrangimentos e das potencialidades que eles inscreveram no projecto. No estado actual das coisas, eles estão presentes mas invisíveis, influentes mas mudos e inacessíveis, os “ fantasmas » do estaleiro.

As implicações são numerosas sobre as competências, a definição dos valores e dos papéis profissionais, os instrumentos técnicos, os sistemas de gestão e de atribuição de recursos. Para que uns e outros sejam mobilizados num “verdadeiro " diálogo sincrónico e situado, para além de uma concertação formal, eles devem desenvolver a sua compreensão mútua, a estrutura de papéis e a sua aptidão para improvisarem juntos (Weick, 1998; Weick, \& Roberts, 1993). Os sistemas de incitação devem ser adaptados. Os procedimentos de constituição de equipas devem ser modificados. Se aos engenheiros de projecto confiamos uma missão de acompanhamento dos estaleiros do qual asseguraram o estudo prévio, a sua avaliação deve integrar essa responsabilidade. Se as chefias de proximidade do estaleiro devem desempenhar um papel na concepção e na planificação, elas devem estar afectadas ao novo estaleiro, pelo menos a tempo parcial, suficientemente cedo. Elas devem também adquirir competências em termos de leitura de planos e de análise de riscos. Os instrumentos de simulação 3D poderiam emergir como uma ligação natural entre a análise dos factores de risco a montante e a preparação das equipas operacionais nas tarefas críticas no estaleiro. Os orçamentos deveriam atribuir tempo e meios às sessões de re-planificação durante a construção e à preparação a curto termo das tarefas críticas. Enfim, todos os actores deveriam estar conscientes de que o que se joga nesse processo, não é a concepção de sistemas técnicos, mas a da actividade colectiva, a sua própria actividade colectiva, processo vivo e parcialmente imprevisível.

\section{Conclusão}

Os desafios desta investigação sobre a actividade colectiva conjunta (os processos) são teóricos, epistemológicos, metodológicos e práticos.

Dum ponto de vista teórico, por razões históricas (Lorino, 1989), a investigação em gestão tendeu a ver as organizações mais como sistemas de tomada de decisão do que como sistemas de actividade, com importantes consequências no estatuto dos instrumentos de gestão, vistos como processadores de informação e de apoios à decisão, e o raciocínio dos actores, assimilado ao tratamento racional da informação (Swieringa, \& Weick, 1987). A investigação aqui evocada procura contribuir para a construção de um paradigma da organização mais fundado na actividade do que na decisão.

Os desafios também são epistemológicos. Pretender “ observar " uma experiência sem dela ser parte activa revela ilusão de observação (“onlooker's fallacy), criticada por Mary Parker Follett (Follett, 1924). A actividade “conhecedora " do investigador e a actividade "a conhecer» são consubstanciais. O investigador pode construir uma compreensão da actividade estudada, mas não um conhecimento externo e transcendente. Esta compreensão é dialógica e aparece como uma resposta : " toda a compreensão é activa e já o germe de uma resposta " (Voloshinov, 1977, citado por 
Todorov, 1981). A investigação sobre as organizações e a actividade colectiva poderia então referir-se a uma epistemologia de compreensão para a acção, mais do que uma epistemologia da verdade na acepção das ciências físicas. De um ponto de vista metodológico, uma tal epistemologia da compreensão apela a métodos de inquérito cooperativo (Reason, 1988; Heron, 1996), que evidencia a activa participação dos actores da organização como co-investigadores.

Os desafios são igualmente práticos. O papel central do inquérito colectivo nas dinâmicas organizacionais questiona o papel e os métodos do gestor bem como os do investigador. $\mathrm{O}$ inquérito não pode privar-se dos actores do processo. Qual é então a contribuição específica dos gestores ? Eles não são peritos da substância da actividade colectiva. Mas, em numerosos casos, o inquérito reflexivo ocorre de forma balbuciante e informal. Os gestores têm um papel essencial a desempenhar no reconhecimento dessas formas nascentes, na legitimação da sua importância para a aprendizagem organizacional e na atribuição de espaço, tempo e recursos necessários ao seu desenvolvimento. Eles têm um papel de especialistas do inquérito, para assinalar as dissonâncias cognitivas, desencadear o inquérito e favorecer-lhe o desenvolvimento.

Enfim, os investigadores são confrontados com um desafio maior da estruturação científica. A investigação sobre “a concepção para a segurança » integra necessariamente a concepção da organização e a concepção da actividade, estreitamente imbricadas. Para progredir significativamente no domínio dos desempenhos da actividade (aqui, a segurança), é necessário que se desenvolva a cooperação entre " ciências da actividade " e " ciências da organização ", para além das fronteiras disciplinares entre ergonomia, psicologia do trabalho, por um lado, gestão ou sociologia das organizações, por outro lado.

\section{BIBLIOGRAFIA}

Bakhtine, M., sous le nom de Voloshinov, V.N. (1925). “En-deça du social (Po tu storonu social'nogo) », in Zvezda, Moscou, cité par Todorov, T. (1981), Mikhil Bakhtine, le principe dialogique. Paris : Seuil.

Bakhtine, M., sous le nom de Voloshinov, V.N. (1926). “Le discours dans la vie et le discours en poésie », in Zvezda, Moscou, 6, traduit par Todorov, T. (1981), Mikhail Bakhtine, le principe dialogique. Paris : Seuil.

Bakhtine, M. or Medvedev, P.N. (1928). Fromal' nyj metod v literaturovedenii (The Formal Methodin Litterary Studies), Leningrad, quoted by Todorov (1984).

Bakhtine, M. (1970). La poétique de Dostoïevski. Paris : Seuil. Bakhtine, M. (1978). Esthétique et théorie du roman. Paris : Gallimard.

Bakhtine, M. (1986). Speech Genres and Other Late Essays (Caryl Emerson and Michael Holquist Eds.). Austin : University of Texas Press.

Chandler, A.D. Jr. (1977). The Visible Hand. The Managerial Revolution in American Business. Cambridge (Mas) and London : The Belknap Press of Harvard University Press. 
Clark, K.B., \& Fujimoto, T. (1991). Product Development Performance : Strategy, Organization, and Management in the World Auto Industry. Cambridge (Mass) : Harvard Business School Press.

Clot, Y. (1999). La fonction psychologique du travail. Paris : Presses Universitaires de France.

Clot, Y., \& Faita, D. (2000). Genres et styles en analyse du travail. Concepts et méthodes.

Travailler, 4, 7-42.

Coriat, B. (1994). L'atelier et le chronomètre. Essai sur le taylorisme, le fordisme et la production de masse. Paris : Christian Bourgois. Dewey, J. (1902). The child and the curriculum. Chicago : University of Chicago Press.

Dewey, J. (1916-1983). Democracy and education : An introduction to the philosophy of education. New York : Mac Millan.

Dewey, J. (1938), Logic : The theory of enquiry. New York : Henry Holt. [Traduction française : Logique : la théorie de l'enquête.Paris : PUF (1967)].

Durkheim, E. (1893-2007). De la division du travail social. Paris : PUF. Téléchargeable : http:// classiques. uqac.ca/classiques/Durkheim_emile/division_du_travail/division_travail.html Follett, M.P. (1924). The Creative Experience. New York : Green and Company.

Girin, J. (1995). Les agencements organisationnels. In F. Charue-Duboc (Ed.), Des savoirs en action (pp. 233-279). Paris, L’Harmattan.

Hammer, M. (1990). Reengineering work : Don't automate, obliterate.

Harvard Business Review, 68, (4), 104-112.

Hatchuel, A., Le Masson, P., \& Weill, B. (2002). De la gestion des connaissances aux organisations orientées conception. Revue internationale des sciences sociales, 1-171, 7-42.

Heron, J. (1996). Co-operative inquiry : Research into the human condition. London : Sage publications.

Imai, M. (1990). Kaizen, la clé de la compétitivité japonaise. Paris : Eyrolles.

James, W. (1907). Pragmatism. New York, London : Longmans, Green. Kaplan, R. (1984).

Yesterday's Accounting Undermines Production.

Harvard Business Review, 62, 95-101.

Kaplan, R. S., \& Johnson H. T. (1987). Relevance Lost. Boston : Harvard Business School Press.

Lave, J., \& Wenger, E. (1991). Situated learning : Legitimate peripheral participation. Cambridge (Mass.) : Cambridge University Press.

Lorino, Ph. (1987). Les saturniens. Paris : La Découverte.

Lorino, Ph. (1989). L'économiste et le manageur. Paris : La Découverte. Lorino, Ph. (1991). Le contrôle de gestion stratégique. Paris : Dunod. Lorino Ph. (1995). Le déploiement de la valeur par les processus. Revue Française de Gestion, 104, 55-71.

Lorino, Ph. (2007). Process based management, dialogism and the reflexive inquiry of collective activity. The case of work safety in the building industry. Paris : Essec Research Center, DR-07013 mai 07.

Midler, Ch. (1993). L'auto qui n'existait pas, management des projets et transformation de l'entreprise. Paris : Interéditions. 
Midler, Ch., \& Lenfle, S. (2003). Gestion de projet et innovation. In Ph. Mustar, \& H. Penan (Eds.), L'encyclopédie de l'innovation (pp. 4969). Paris : Economica.

Peirce, Ch.S. (1958). Collected Papers. Cambridge (Mass.) : Harvard University Press. [Traduction française : Oeuvres complètes, Paris : Cerf].

Perrow, Ch. (1984). Normalaccidents : Livingwithhigh-risk technologies.

Princeton : Princeton University Press.

Perrow, Ch. (1999). Organizing to Reduce the Vulnerabilities of Complexity. Journal of Contingencies and Crisis Management, 7, (3), 150-155.

Ponssard, J.P., \& Tanguy, H. (1993). Planning in firms as an interactive process. Theory and Decision, 34, 139-159.

Raelin, J. (1999). Preface. Management Learning, 30, (2), 115-125.

Reason, P. (Ed.) (1988). Human inquiry in action : Developments in new paradigm research. London : Sage Publications.

Smith, D.E. (Ed.) (2006). Institutional Ethnography as Practice. Lanham (MD) : Rowman and Littlefield.

Swieringa, R.J., \& Weick, K.E. (1987). Management Accounting and Action. Accounting, Organizations and Society, 12, (3), 293-308.

Taylor, F.W. (1911-1972). The principles of scientific management.

Westport (Connecticut) : Greenwood Press Publishers.

Todorov, T. (1981). Mikhail Bakhtine, le principe dialogique. Paris : Seuil. Tricard, B. (2009). La genèse organisationnelle du risque d'accidents sur les chantiers de construction : une approche dialogique de l'activité collective organisée. Thèse de doctorat, Université de

Paris X Nanterre, 30 mars.

Vernant, D. (1997). Du discours à l'action, études pragmatiques. Paris : P.U.F. Voloshinov, V. N./ Bakhtine, L.S. (1977, orig. 1929) (discussed attribution). Le marxisme et la philosophie du langage. Paris : Minuit [English translation : Voloshinov, V. N. (1973) Marxism and the Philosophy

of Language, Cambridge (Mas) : Seminar Press, in liaison with the Harvard University Press and the Academic Press Inc.].

Vygotski, L. (1997). Pensée et langage. Paris : La Dispute.

Weick, K.E. (1979). The Social Psychology of Organizing. Reading (Mas) : Addison-Wesley Pub.

Weick, K.E. (1998). Introductory Essay. Improvisation as a Mindset for Organizational Analysis. Organization Science, 9 (5), 543-555.

Weick, K.E., \& Roberts, K.H. (1993). Collective Mind in Organizations : Heedful Interrelating on Flight Decks. Administrative Science Quarterly, 38, 357-381.

Wenger E., \& Snyder, W. (2000). Communities of practice : the organizational frontier. Harvard Business Review, Jan-Feb., 139-145.

Widerberg, K. (2004). Institutional Ethnography - Towards a Productive Sociology. An Interview with Dorothy E. Smith. Sosiologisk tidskrift, 12, 179-184 


\section{NOTAS}

1. European Foundation for Quality Management.

2. Activity-Based Costing.

3. Enterprise Resource Planning.

4. 'Systems Applications and Products for data processing', nome da empresa alemã que desenvolveu este software de gestão integrada.

5. Esta experiência foi realizada por Benoît Tricard, investigador doutorando do ESSEC e pelo autor deste texto.

6. Como exemplos um pouco triviais mas ilustrativos de signos tendo uma função prática sem passar por uma qualquer representação, citemos: o nó no lenço, que desencadeia uma acção sem ter nenhum valor de representação, ou a palavra da linguagem corrente, que reenvia para o seu objecto por uma ligação puramente simbólica (a palavra «mesa» não tem nenhuma semelhança com o objecto mesa...).

7. A palavra "género» deve aqui ser entendida no sentido bastante geral que lhe dá Dewey, para além da noção de "género profissional» posto em relevo por Clot e Faïta: trata-se de toda a colocação em equivalência de actividades destinada a definir classes de actividades, um vocabulário genérico da actividade.

8. Esta investigação foi objecto de um projecto pluridisciplinar (psicologia do trabalho e gestão), envolvendo o laboratório «Clinique de l'Activité» do CNAM e o ESSEC, e posto em prática, por um lado, por Yves Clot, professor no CNAM, e Julie Duboscq, investigadora no CNAM, por outro lado, pelo autor do presente artigo e Benoît Tricard, investigador no ESSEC.

\section{RESUMOS}

A primeira parte do artigo propõe uma teorização da noção de " actividade colectiva ». A noção de "processo", muito presente na investigação e nas práticas da gestão, reenvia para a actividade colectiva conjunta, combinação de actividades locais que fazem apelo a competências distintas. A configuração dos processos de uma organização é contingente e definida pelo inquérito reflexivo dos actores sobre a sua própria actividade colectiva. 0 processo e o inquérito reflexivo que o constrói são dialógicos (Todorov, 1981) : o seu sentido constrói-se de maneira dinâmica, através das interacções entre actores. A actividade colectiva é mediatizada semioticamente. O inquérito no sentido pragmatista (Dewey, 1938) procura fornecer respostas operatórias para situações de dúvida, combinando raciocínio e acção e introduzindo no processo uma dimensão avaliativa. A actividade colectiva, através do inquérito, inscreve-se numa configuração sócio-espácio-temporal específica, o seu " cronótopo ", que induz os contornos da comunidade de actores implicada e o referencial de sentido ao qual o inquérito pode apelar.

$\mathrm{Na}$ segunda parte, o artigo apresenta um estudo de caso sobre uma abordagem colectiva empreendida com a finalidade de melhorar a segurança no trabalho nos estaleiros da construção. O estudo está focado sobre o processo “ conceber e planificar o projecto de construção ». É adoptado um método de inquérito colectivo reflexivo sobre o processo, implicando os seus actores como co-investigadores. Um grande problema para a segurança identificado pelo grupo é a separação profunda, em termos gestionários e culturais, entre concepção, preparação e realização. O sentido do trabalho e das situações constrói-se através de dois processos de cronótopos separados: “conceber e planificar o projecto» e "realizar a obra ». A análise 
proposta conduz à revisão em profundidade da definição dos universos profissionais, dos referenciais de sentido e dos conceitos, abolindo a distinção entre mundo da concepção e mundo da execução tal como é habitualmente compreendida nas empresas e pelos investigadores. As implicações são numerosas para as competências, a definição dos valores e dos papéis profissionais, os instrumentos técnicos, os sistemas de gestão e a atribuição de recursos.

La primera parte del texto propone teorizar la noción de "actividad colectiva". La noción de "proceso", muy presente tanto en la investigación como en las prácticas de gestión, hace referencia a la actividad colectiva conjunta, combinación de actividades locales que recurren a competências diferentes. La configuración de los procesos de una organización esta supeditada y es definida por la investigación reflexiva de los actores sobre su propia actividad colectiva. El proceso y la investigación reflexiva que lo construye son dialógicos (Todorov, 1981) : su sentido se construye en un modo dinámico, a través de las interacciones entre actores. La actividad colectiva está mediatizada semióticamente. La investigación de tipo pragmático (Dewey, 1938) intenta aportar respuestas operativas a las situaciones de duda, mezclando razonamiento y acción, e introduciendo en el proceso una dimensión de evaluación. A través de la investigación, la actividad colectiva se inscribe en una configuración socio-espacio-temporal específica, su “ cronotopo ». Esta induce los contornos de la comunidad de actores implicada y el referencial de sentido al cual puede recurrir la investigación.

En su segunda parte, el texto presenta un estudio de caso acerca de una aproximación colectiva puesta en marcha para mejorar la seguridad en el trabajo en obras de construcción. El estudio se centra en el proceso de " diseñar y planificar el proyecto de construcción”. Se adopta un método de investigación colectiva reflexiva sobre el proceso, la cual implica tanto a los actores del proceso como a los co-investigadores. Un problema de máxima importancia para la seguridad que ha sido identificado por el grupo es el corte profundo, en términos de gestión y culturales, entre diseño preparación y realización. El sentido del trabajo y de las situaciones se construye a través de dos procesos de cronotopos diferentes : “ diseñar y planificar el proyecto » y " realizar la obra ». El análisis propuesto conduce a revisar en profundidad la profundidad de los universos profesionales, referenciales de sentido y de los conceptos, aboliendo la distinción entre el mundo del diseño y el mundo de la realización, como es generalmente entendida por las empresas y los investigadores. Las implicaciones son muy numerosas en cuanto a las competencias, la definición de los valores y de los roles profesionales, las herramientas técnicas, los sistemas de gestión y la asignación de recursos.

La première partie du texte propose une théorisation de la notion d"' activité collective ». La notion de "processus", très présente dans la recherche et les pratiques de gestion, renvoie à l'activité collective conjointe, combinaison d'activités locales faisant appel à des compétences distinctes. La configuration des processus d'une organisation est contingente et définie par l'enquête réflexive des acteurs sur leur propre activité collective. Le processus et l'enquête réflexive qui le construit sont dialogiques (Todorov, 1981): leur sens se construit de manière dynamique, à travers les interactions entre acteurs. L'activité collective est médiatisée sémiotiquement. L'enquête au sens pragmatiste (Dewey, 1938) tente d'apporter des réponses opératoires à des situations de doute, en mêlant raisonnement et action et en introduisant dans le processus une dimension évaluative. L'activité collective, à travers l'enquête, s'inscrit dans une configuration socio-spatio-temporelle spécifique, son "chronotope ", qui induit les contours de la communauté d'acteurs concernée et le référentiel de sens auquel l'enquête peut faire appel.

Dans sa deuxième partie, le texte présente une étude de cas sur une démarche collective engagée pour améliorer la sécurité du travail sur les chantiers de bâtiment. L'étude est centrée sur le processus " concevoir et planifier le projet de construction ». Une méthode d'enquête collective réflexive sur le processus est adoptée, impliquant les acteurs du processus comme cochercheurs. Un problème majeur pour la sécurité identifié par le groupe est la coupure profonde, en termes 
managériaux et culturels, entre conception préparation et réalisation. Le sens du travail et des situations se construit à travers deux processus de chronotopes séparés : “ concevoir et planifier le projet » et “ réaliser le chantier». L'analyse proposée conduit à revoir en profondeur la définition des univers professionnels, des référentiels de sens et des concepts, en abolissant la distinction entre monde de la conception et monde de la réalisation telle qu'elle est généralement comprise dans les entreprises et par les chercheurs. Les implications sont nombreuses pour les compétences, la définition des valeurs et des rôles professionnels, les outils techniques, les systèmes de gestion et l'allocation de ressources.

The first part of the article offers a theorization of the concept of "collective activity." The notion of "process", very present in management research and practices, refers to joint collective activity, i.e. collective activity combining local activities which involve distinct competences. The configuration process of an organization is contingent and defined through reflexive inquiry of actors on their own collective activity. The processes and the reflexive inquiries which are constructed are dialogical (Todorov, 1981), i.e. their sense is built through interactions between actors. The collective activity is semiotically mediated. Pragmatist inquiry (Dewey, 1938) tries to build practical and theoretical responses to uncertain situations, by intricately combining reasoning and action and by introducing an evaluative dimension. Collective activity, through inquiry, is given a specific socialspatialtemporal configuration, its "chronotope" which leads to the shaping of the community of concerned actors and the frame of reference which can be used by the study. In the second part, a case study is presented about a collective attempt to improve work safety in a building company. The study focuses on the "design and planning process of the construction project". A collective reflexive inquiry method was adopted involving the actors, involved in the process, as co-researchers. A major problem for safety identified by the working group is the deep divide, in managerial and cultural terms, between design-planning-preparation and building. The sense of work and situations is shaped through two distinct chronotopes: "design and planning process of the construction project" and "carrying out the building site". The proposed analysis leads to an indepth review of the definition of the professional world, interpreting frameworks and concepts, eliminating the distinction between the world of design and building as it is generally understood and applied by firms and researchers. There are numerous implications for the skills, the definition of professional values and roles, technical tools, the management systems and resource allocation.

\section{ÍNDICE}

Palabras claves: actividad colectiva, obras de construcción, cronotopo, dialogismo, investigación, mediación semiótica, pragmatismo, proceso, seguridad en el trabajo

Keywords: building sites, chronotope, collective activity, dialogism, inquiry, pragmatism, process, semiotic mediation, work safety

Palavras-chave: actividade colectiva, estaleiros da construção, cronótopo, dialogismo, inquérito, mediação semiótica, pragmatismo, processo, segurança do trabalho

Mots-clés: activité collective, chantiers de construction, chronotope, dialogisme, enquête, médiation sémiotique, pragmatisme, processus, sécurité du travail 


\section{AUTORES}

\section{PHILIPPE LORINO}

ESSEC Business School, Av. Bernard Hirsch B.P. 5010595021 Cergy, France

lorino@essec.fr 